\title{
Effectiveness of Sameti Trainings: A Study in Uttarakhnad
}

\author{
Rifat Haneef ${ }^{1}$, S.K. Kashyap ${ }^{1}$ and Taufiq Ahmad ${ }^{2 *}$ \\ ${ }^{1}$ Department of Agricultural Communication, GBPUA\&T, Pantnagar, Uttarakhand 263145 \\ ${ }^{2}$ College of Forestry, VCSG Uttarakhand University of Horticulture and Forestry, Ranichauri, \\ Tehri Garhwal-249 199, India \\ *Corresponding author
}

\section{A B S T R A C T}

\section{Keywords}

SAMETI (State Agriculture

Management \&

Extension

Training institute),

Training, Trainees,

Effectiveness

Article Info

Accepted:

20 July 2020

Available Online:

10 August 2020
The study effectiveness of SAMETI trainings measured through Kirkpatrick model, total 10 training programmes were selected purposively under the present study. Out of total 107 trainees 73 trainees gave the responses. In order to provide answer to selected research questions, analytical research design was used. Majority of the trainees 76.72 percent reported that there was almost equal proportion of theory and practical, 91.79 percent reported that trainers always used the common language during the different training sessions, 83.57 percent expressed that trainers were completely concerned about trainee's problems.

\section{Introduction}

Training Needs Assessment is the method of determining if a training need exists and, if it does, what training is required to fill the gap. Training need assessment is considered to be the integral part of well designed training programme. Training needs are closely linked to learning: the target population is looked at more closely to determine the actual content, context and delivery method of performance intervention (Ahmed, et al., 2019). A systemically arranged training programme aids in production of desirable changes in the behavior of the trainnes. The right age to train trainees is when they are young. Training needs and effectiveness of the trainings for extension personnel can be defined in terms of gap between job requirement and job performance (Mishra, 1990). The training needs of agricultural school masters can be worked out with the help of Training Need Quotient developed by Sidhu (1973). The training needs of extension personnel also changes from time to time due to rapid changes in technology and information delivery systems. Thus, this call for training needs assessment of extension personnel 
before conducting a training programme (Nongtdu et al., 2012).

The gap between the present status and desired status may indicate problems that in turn can be translated into a training need. Agripreneurship is an employment strategy that can lead to economic self-sufficiency of rural people. Agripreneurship development through training is a key elements for the promotion of Micro, Small and Medium Enterprises (MSMEs), particularly, the first generation agripreneurs (Ahmed, et al., 2011) through trainings. SAMETI (State Agriculture Management \& Extension Training institute) is an autonomous body with greater flexibility in structure and functioning and is responsible for organizing need based training programmes for agriculture and allied sectors, and exposure visits for members of the farming community (Haneef et al., 2019). This institution is linked to other technical and management institutes at the state level to provide the desired training inputs. SAMETI (State Agriculture Management \& Extension Training institute) functions under the technical guidance of MANAGE, Hyderabad. SAMETI conducts programme-oriented research in the area of agricultural extension management as a sequel to provide feedback from training programmes. SAMETI has documented its efforts through publication of leaflets, booklets and postures for effective and sustainable transfer of frontier agriculture technologies for the benefit of the farming community.

The vision of SAMETI is to see self-reliant and healthy rural population with rich agricultural knowledge and good marketing intelligence. The mission of the Institute is to facilitate the field staff of the State Department of Agriculture and allied departments to improve the efficiency of extension services through better management by following bottom up, farmer participatory and decentralized planning and control approaches. The ultimate goal of the institute is to empower the farming community for improved management of production resources and agricultural operations for better living.

\section{Materials and Methods}

The study was conducted in G.B. Pant University of Agriculture and Technology of Uttarakhand state. SAMETI in Uttarakhand is located at Directorate of Extension Education, Govind Ballabh Pant University of Agriculture and Technology, Pantnagar, U. S. Nagar. Training cell of State Agricultural Management and Extension Training Institute is engaged in conducting training program for middle level and grass root level agriculture and allied subject extension functionaries. A list of training programs to be conducted by SAMETI was collected from the training cell. Total 26 trainings were to be conducted during this period. The total 10 trainings were taken under this research. All the trainees who participated in the selected ten trainings conducted were selected purposively for the present study. Total 107 trainees participated in selected trainings who were contacted for data gathering. Out of 107 trainees total 73 trainees gave the responses. In order to provide answer to selected research question, analytical research design was used (Haneef et al., 2016).

\section{Results and Discussion}

\section{Effectiveness of SAMETI Trainings}

This part of the chapter deals with the effectiveness of SAMETI trainings on selected indicators. Effectiveness of training was measured through Kirkpatrick model under following heads:

-Opinion of trainees on training methodology 
- Trainees opinion about the trainers

Opinion of trainees on training
methodology

This part of the findings deals with describing the trainees' opinion regarding organization of training program. Various aspects studied in this section are presented as follows:

\section{Extent of use of various instructional strategies during training}

'Trainees' opinion regarding extent of use of various instructional strategies during various training session was collected on three point continuum i.e. regular use, sometimes and never. The data regarding this indicator has been presented in Table 1. It is revealed from the data that all the trainees (100 percent) expressed that lecture was the most regularly used method of training. Practical's were used for specific trainings but they were not regularly used in all the trainings as revealed by the data which says that 72.61 percent respondents reported that practical's were sometimes used whereas 15.06 percent trainees reported that practical's were never used group discussions and visits were sometimes used in most of the trainings as reported by majority of the respondents. Most of the trainees (43.84 percent) reported that demonstrations were never used in the trainings whereas 42.47 percent trainees reported that demonstrations were sometimes used. Most of the trainees reported that question-answer sessions were sometimes used as instructional strategy.

\section{Proportion of theory and practical in training content}

Opinion of the trainees about the proportion of theory and practical in training content has been presented in Table 2. As discussed with the trainees it was observed that though lecture was regularly used in most of the trainings but practical's including demonstration, field visits, etc. were also clubbed with the theories as revealed by 76.72 percent respondents who were found to be satisfied with the extent of practical in comparison to theories.

Only 23.28 percent respondents reported that their trainings were theory dominated as compared to practical orientation.

It was observed that the proportion of theory and practical were dependent on subject of training program and some training programs were comparatively practical oriented as compared to other topics where theories dominated throughout the training.

\section{Extent of use of audio-visual aids}

Trainee's opinion regarding extent of use of various audio-visual aids during various training session was collected on three point continuum i.e. regular use, sometimes and never. The data related to opinion of trainees regarding extent of use of different audiovisual aids that were used during different training sessions has been presented in Table 3.

The above data reveals that all the trainings were not uniformly supported with audiovisual aids. It was observed that only 36.98 percent trainees got posters as regularly used audio-visual aids and 24.66 percent trainees got chalk boards as regularly used audiovisual aids. It indicates that all other trainings were mostly dependent on lectures without support of audio-visual aids.

Charts, chalkboard, PowerPoint and posters were found to be the audio-visual aids that were occasionally used as reported by majority of the respondents. 


\section{Supply of follow up instructional material}

Data related to supply of follow up instructional material to the trainees has been presented in Table 4.

It is clear from the Table that all the trainees got a booklet that contained various topics that were covered during different training sessions as a follow up instructional material. Some trainees (23.28 percent) also got folders as a follow up instructional material. Cassettes or any other material were not provided to the trainees after the completion of training as a follow up instructional material. From the above data it is obvious that follow up instructional material was provided to the trainees in all the trainings but it was limited to printed material only.

\section{Usefulness of follow up instructional material provided to trainees}

Data related to usefulness of follow up instructional material provided to the trainees as perceived by them has been presented in Table 5.

It is clear from the data that majority of the trainees 67.12 percent perceived that the instructional material provided to them was useful but 32.88 percent trainees expressed that instructional material was not useful at all. As discussed with the trainees it was revealed that few of them perceived the training materials as too theoretic rather than that of practical utility. Some of the trainees reported about the training material as too scientific and difficult to understand. Language of the provided material was also found to be bookish and tough as perceived by few of the trainees. The trainees also reported that the materials were mostly in textual form with less inclusion of photographs, graphics and other illustrations. These reasons may have resulted in responses of 32.88 percent trainees who got the instructional materials not useful at all.

\section{Trainees opinion about the trainers}

This part of chapter describes trainees' opinion about the trainers regarding their knowledge, teaching skills and behaviour during the different training sessions. Various aspects studied in this section are presented as follows:

\section{Trainees' opinion about trainer's knowledge about the content}

Data related to trainers' knowledge about the content taught during training as perceived by trainees' has been presented in Table 6 .

It is clear from the Table that all the trainees expressed that all the trainers involved in training had very good knowledge about the content they taught during training. None of trainees stated trainer's knowledge as satisfactory and not satisfactory. It can be summarized that the trainers who conducted different training sessions had sound knowledge of the content they taught.

\section{Trainees' opinion about trainers' ability to make the things understandable}

Data related to trainer's ability to make things understandable as perceived by trainees has been presented in Table 7 .

It is observed from the Table that majority of the trainees 90.42 percent felt that ability of the trainers' to make things understandable during different training sessions was very good. Some of the trainees 9.58 percent said that trainers' ability to make things understandable was satisfactory and none of them stated it as unsatisfactory. It can be concluded that the trainers treated content very skillfully which was easily understood by the trainees. 
Trainees' opinion about trainers' skills in working with trainees

Data related to trainees' opinion about trainers' skills in working with trainees has been presented in Table 8 .

It is evident from the Table that all the trainees expressed that trainers' skill in working with the trainees was very good and none of them reported it as satisfactory and not satisfactory. It can be inferred that irrespective of background and education of the trainees, the trainers handled them very well.

Trainees' opinion about extent of trainers' consideration for trainees' needs and interests

Data related to extent of trainers' consideration for trainees' needs and interests as perceived by trainees has been presented in Table 9.

It is clear from the Table that all the trainees expressed that all the trainers were very much concerned about the needs and interests of the trainees.

\section{Trainees' opinion about trainer's skills in handling differences among trainees}

The data related to trainer's skills in handling differences among trainees as perceived by trainees' has been presented in Table 10 .

It is clear from the Table that almost all the trainers (98.64 percent) had good skills in handling differences among trainees. It can be concluded that the trainers were capable to manage the differences among the trainees.

Trainees opinion about use of common language by trainers' during training

Data related to use of common language by trainers' during training as expressed by trainees' has been presented in table 11. It is observed from the Table that majority of the trainees (91.79 percent) expressed that trainers always used the common language during the different training sessions and 8.21 percent of the trainees expressed that trainers' used English and more scientific language and toned down to common language sometimes only. From the data it can be inferred that mostly trainers avoided the use of complicated language during the training sessions.

\section{Trainees' opinion about trainers' personality}

Data related to trainees' opinion about the trainers' personality has been presented in Table 12.

It is clear from the above Table that all the trainees expressed that the trainers had impressive personality and none of them expressed trainers' personality as not impressive. It can be concluded that all the trainees were influenced by the trainer's personality during the training sessions.

\section{Trainees' opinion about trainers' concern to trainees problem}

Data related to trainers' concern to trainees' problem as perceived by trainees has been presented in Table 13.

It is revealed from the above Table that majority of the trainees (83.57 percent) expressed that trainers were completely concerned about trainees problems and only 16.43 percent of the trainees reported that trainers were concerned to trainees problems up to some extent. From the above data it can be inferred that mostly the trainers demonstrated concern to the felt problems of trainees which made the trainees feel comfortable. 
Table.1 Distribution of trainees based on their opinion about extent of use of various instructional strategies during training

\begin{tabular}{|c|c|c|c|c|}
\hline S. No. & \multirow{2}{*}{ Instructional strategies } & \multicolumn{3}{|c|}{ Response (N=73) } \\
\cline { 3 - 5 } & & Regular use & Sometimes & Never \\
\hline $\mathbf{1 .}$ & Lecture & $73(100.00)$ & $0(0.00)$ & $0(0.00)$ \\
\hline $\mathbf{2 .}$ & Practical & $9(12.33)$ & $53(72.61)$ & $11(15.06)$ \\
\hline $\mathbf{3 .}$ & Group Discussion & $0(0.00)$ & $63(86.31)$ & $10(13.69)$ \\
\hline $\mathbf{4 .}$ & Visits & $0(0.00)$ & $64(87.67)$ & $9(12.33)$ \\
\hline $\mathbf{5 .}$ & Demonstration & $10(13.69)$ & $31(42.47)$ & $32(43.84)$ \\
\hline $\mathbf{6 .}$ & Question and Answer & $0(0.00)$ & $61(83.56)$ & $12(16.44)$ \\
\hline
\end{tabular}

Note: Figures in parenthesis indicate the percentage in respective category.

Table.2 Distribution of trainees based on their opinion about the proportion of theory and practical in training content

\begin{tabular}{|c|c|c|c|}
\hline S. No. & $\begin{array}{c}\text { Proportion of theory and } \\
\text { practical }\end{array}$ & Frequency & Percentage \\
\hline $\mathbf{1 .}$ & More theory and less practical & 17 & 23.28 \\
\hline $\mathbf{2 .}$ & $\begin{array}{c}\text { Almost equal proportion of theory } \\
\text { and practical }\end{array}$ & 56 & 76.72 \\
\hline $\mathbf{3 .}$ & More practical and less theory & 0 & 0.00 \\
\hline & Total & $\mathbf{7 3}$ & $\mathbf{1 0 0}$ \\
\hline
\end{tabular}

Table.3 Distribution of trainees based on their opinion about extent of use of audio-visual aids. $(\mathrm{N}=73)$

\begin{tabular}{|c|c|c|c|c|}
\hline \multirow{2}{*}{ S. No. } & Audio-Visual aids & \multicolumn{3}{|c|}{ Response (N=73) } \\
\cline { 3 - 5 } & & Regular use & Sometimes & Never \\
\hline $\mathbf{1 .}$ & Model/Specimen & $0(0.00)$ & $29(39.72)$ & $44(60.28)$ \\
\hline $\mathbf{2 .}$ & Posters & $27(36.98)$ & $37(50.68)$ & $9(12.34)$ \\
\hline $\mathbf{3 .}$ & Video & $0(0.00)$ & $15(20.54)$ & $58(79.46)$ \\
\hline $\mathbf{4 .}$ & Tape recorder & $0(0.00)$ & $0(0.00)$ & $73(100.00)$ \\
\hline $\mathbf{5 .}$ & PowerPoint presentation & $0(0.00)$ & $52(71.23)$ & $21(28.77)$ \\
\hline $\mathbf{6 .}$ & Transparencies & $0(0.00)$ & $0(0.00)$ & $73(100.00)$ \\
\hline $\mathbf{7 .}$ & Chalk board & $18(24.66)$ & $55(75.34)$ & $0(0.00)$ \\
\hline $\mathbf{8 .}$ & Charts & $0(0.00)$ & $64(87.66)$ & $9(12.34)$ \\
\hline $\mathbf{9 .}$ & Photos & $0(0.00)$ & $0(0.00)$ & $73(100.00)$ \\
\hline
\end{tabular}

Note: Figures in parenthesis indicate the percentage in respective category. 
Table.4 Distribution of trainees based on follow up instructional material they got

$(\mathrm{N}=73)$

\begin{tabular}{|c|c|c|c|}
\hline S. No. & Instructional material & Frequency & Percentage \\
\hline $\mathbf{1 .}$ & Booklet & 73 & 100 \\
\hline $\mathbf{2 .}$ & Cassette & 0 & 0.00 \\
\hline $\mathbf{3 .}$ & Folder & 17 & 23.28 \\
\hline
\end{tabular}

Table.5 Distribution of trainees based on the usefulness of instructional material as perceived by them

\begin{tabular}{|c|c|c|c|}
\hline S. No. & $\begin{array}{c}\text { Usefulness of instructional } \\
\text { material }\end{array}$ & Frequency & Percentage \\
\hline 1. & Very useful & 11 & 15.07 \\
\hline $\mathbf{2 .}$ & Useful up to some extent & 38 & 52.05 \\
\hline $\mathbf{3 .}$ & Not useful at all & 24 & 32.88 \\
\hline & Total & $\mathbf{7 3}$ & $\mathbf{1 0 0}$ \\
\hline
\end{tabular}

Table.6 Distribution of trainees based on their opinion about trainers' knowledge about the content

\begin{tabular}{|c|c|c|c|}
\hline \multicolumn{4}{|c|}{$(\mathrm{N}$} \\
\hline S. No. & Trainers' knowledge about the content & Frequency & Percentage \\
\hline 1. & Very good & 73 & 100 \\
\hline 2. & Satisfactory & 0 & 0.00 \\
\hline 3. & Not satisfactory & 0 & 0.00 \\
\hline & Total & $\mathbf{7 3}$ & $\mathbf{1 0 0}$ \\
\hline
\end{tabular}

Table.7 Distribution of trainees based on their opinion about trainers' ability to make the things understandable

$(\mathrm{N}=73)$

\begin{tabular}{|c|c|c|c|}
\hline S. No. & Trainers' ability to make the things understandable & Frequency & Percentage \\
\hline $\mathbf{1 .}$ & Very good & 66 & 90.42 \\
\hline $\mathbf{2 .}$ & Satisfactory & 7 & 9.58 \\
\hline $\mathbf{3 .}$ & Not satisfactory & 0 & 0.00 \\
\hline & Total & $\mathbf{7 3}$ & $\mathbf{1 0 0}$ \\
\hline
\end{tabular}

Table.8 Distribution of trainees based on their opinion about trainers' skills in working with the trainees

$(\mathrm{N}=73)$

\begin{tabular}{|c|c|c|c|}
\hline S. No. & Trainers' skills in working with trainees & Frequency & Percentage \\
\hline $\mathbf{1 .}$ & Very good & 73 & 100 \\
\hline $\mathbf{2 .}$ & Satisfactory & 0 & 0.00 \\
\hline 3. & Not satisfactory & 0 & 0.00 \\
\hline & Total & $\mathbf{7 3}$ & $\mathbf{1 0 0}$ \\
\hline
\end{tabular}


Table.9 Distribution of trainees based on their opinion about extent of trainers' consideration for trainees' needs and interests

$(\mathrm{N}=73)$

\begin{tabular}{|c|c|c|c|}
\hline S. No. & Trainers' consideration for trainees' needs and interests & Frequency & Percentage \\
\hline $\mathbf{1 .}$ & Very much concerned & 73 & 100 \\
\hline $\mathbf{2 .}$ & Concerned up to some extent & 0 & 0.00 \\
\hline $\mathbf{3 .}$ & Not concerned at all & 0 & 0.00 \\
\hline & Total & $\mathbf{7 3}$ & $\mathbf{1 0 0}$ \\
\hline
\end{tabular}

Table.10 Distribution of trainees based on their opinion about trainers' skills in handling differences among trainees

\begin{tabular}{|c|c|c|c|}
\hline S. No. & Trainers' skills in handling differences among & Frequency & Percentage \\
& trainees & & \\
\hline 1. & Very well & 72 & 98.64 \\
\hline 2. & Up to some extent & 1 & 1.36 \\
\hline 3. & Not at all & 0 & 0.00 \\
\hline & Total & $\mathbf{7 3}$ & $\mathbf{1 0 0}$ \\
\hline
\end{tabular}

Table.11 Distribution of trainees based on their opinion about use of common language by trainers' during training

\begin{tabular}{|c|c|c|c|}
\hline S. No. & Use of common language by trainers' during & Frequency & Percentage \\
\hline training & Always & 67 & 91.79 \\
\hline 2. & Sometimes & 6 & 8.21 \\
\hline 3. & Never & 0 & 0.00 \\
\hline & Total & $\mathbf{7 3}$ & $\mathbf{1 0 0}$ \\
\hline
\end{tabular}

Table.12 Distribution of trainees based on their opinion about trainers' personality $\quad(\mathrm{N}=73)$

\begin{tabular}{|c|c|c|c|}
\hline S. No. & Trainers' personality & Frequency & Percentage \\
\hline 1. & Impressive & 73 & 100 \\
\hline 2. & Not impressive & 0 & 0.00 \\
\hline & Total & $\mathbf{7 3}$ & $\mathbf{1 0 0}$ \\
\hline
\end{tabular}

Table.13 Distribution of trainees based on their opinion about trainers' concern to trainees problem

\begin{tabular}{|c|c|c|c|}
\hline \multicolumn{5}{|c|}{$(\mathrm{N}=73)$} \\
\hline S. No. & Trainers' concern to trainees' problem & Frequency & Percentage \\
\hline $\mathbf{1 .}$ & Completely & 61 & 83.57 \\
\hline $\mathbf{2 .}$ & Up to some extent & 12 & 16.43 \\
\hline $\mathbf{3 .}$ & Not at all & 0 & 0.00 \\
\hline & Total & $\mathbf{7 3}$ & $\mathbf{1 0 0}$ \\
\hline
\end{tabular}


In conclusion, all the trainees (100 percent) expressed that lecture was the most regularly used method of training. Majority of the trainees (76.72 percent) reported that there was almost equal proportion of theory and practical and were satisfied with the proportion of both in the training content. The trainees reported that posters (36.98 percent) and chalk board (24.66 percent) were most regularly used audio-visual aids. A booklet that contained various topics that were covered during different training sessions was provided to cent percent trainees as a follow up instructional material. Almost half of the trainees (52.05 percent) perceived that the instructional material provided to them was useful up to some extent. Hundred percent trainees reported that all the trainers involved in training had very good knowledge about the content they taught during training. Majority of the trainees (90.42 percent) felt that ability of the trainers' to make things understandable during different training sessions was very good. Hundred percent trainees expressed that trainers' skills in working with the trainees was very good. Hundred percent trainees reported that all the trainers were very much concerned about the needs and interests of the trainees. Almost all the trainees (98.64 percent) expressed that trainers had good skills in handling differences among trainees. Majority of the trainees (91.79 percent) reported that trainers always used the common language during the different training sessions. All the trainees revealed that the trainers had very impressive personality. Majority of the trainees (83.57 percent) expressed that trainers were completely concerned about trainee's problems.

\section{References}

Ahmed T, Hasan S, Haneef R, 2011. Entrepreneurial Characteristics of the Agripreneurs under the Scheme of
Agriclinics \& Agri-business Centres Published in Journal of Community Mobilization and Sustainable Development Vol. 6(2), 145-149, July-December, 2011

Ahmed T, Hasan S, Haneef R. and Riyal R, 2019. Comparative Study of Training Need Assessment of AgriEntrepreneurs under Agri-Clinics and Agri-Business Center Scheme in India. International Journal of Current Microbiology and Applied Sciences (IJCMAS) (2019) 8(4): 22872297

Haneef R, Kashyap S, Ahmad T, Singh P, 2016. Socio-personal, psychological and professional characteristics of the SAMETI trainees: a study of Uttarakhand. Progressive Research An International Journal Print ISSN : 0973-6417, Online ISSN : 2454-6003 Volume 11 (Special-VIII) : 5424-5427 (2016)

Haneef R, Sharma G, Ahmad T, 2019. Constraints Faced by Farmers Practicing Organic Farming in Hill Region of Uttarakhand, India, Published in International Journal of Current Microbiology and Applied Sciences, (2019) 8(5): 1149-1157

https://www.sameti.org/sameti-2.pdf

Mishra D C, 1990. New Directions in Extension Training. Directorate of Extension, Ministry of Agriculture. New Delhi

Nongtdu G, et al, 2012. Training Needs of Agricultural Extension Personnel in Meghalaya, Indian Journal of Hill Farming 25(1):1-8

Sidhu BS, 1973. Training needs of agricultural masters in high school of Punjab. Summaries of extension research by post graduate students 5 . Department of Extension Education, PAU, Ludhiana. 


\section{How to cite this article:}

Rifat Haneef, S.K. Kashyap and Taufiq Ahmad. 2020. Effectiveness of Sameti Trainings: A Study in Uttarakhnad. Int.J.Curr.Microbiol.App.Sci. 9(08): 1979-1988.

doi: https://doi.org/10.20546/ijcmas.2020.908.226 